\title{
KAZIRODZTWO JAKO PRZYKLAD SPORU MIĘDZY PRAWEM NATURALNYM A POZYTYWNYM
}

\begin{abstract}
Streszczenie. Artykuł przedstawia kazirodztwo jako przykład sporu między prawem naturalnym a pozytywnym. Analizie poddano art. 201 k.k., dokonując jej przez pryzmat dóbr prawnych, które zgodnie z poglądami przedstawicieli doktryny artykuł ten ma chronić. W jego treści zakaz kazirodztwa jako rodzaj normy prawnonaturalnej poddany jest ocenie z punktu widzenia koncepcji zarówno maksymalizmu prawnonaturalnego, jak i minimum prawa natury H.L.A. Harta. Artykuł w swojej treści odnosi się również do istotnego braku powszechności penalizacji omawianego zjawiska w ustawodawstwach innych państw europejskich. Autor przyjmuje, że polska, ustawowa penalizacja kazirodztwa spełnia warunki koncepcji minimum prawa natury i tym samym daje wyraz przyjęciu przez ustawodawcę ochrony zasad o charakterze moralnym, obecnych w polskiej kulturze.

Słowa kluczowe: kazirodztwo, prawo naturalne, prawo pozytywne, prawo karne, Hart.
\end{abstract}

Jednym z głównych zrębów filozofii prawa, co na wstępie warto zaznaczyć, jest kwestia relacji, jakie występują pomiędzy prawem pozytywnym (prawem stanowionym) a prawem naturalnym. Problematyka ta dotyczy również kwestii istniejących rozbieżności między jednym prawem a drugim. Zazwyczaj są one rozpatrywane w kontekście sporu dotyczącego zgodności treści prawa z normami moralnymi, które mają się znajdować w prawie naturalnym, lub aksjologicznego uzasadnienia danego rozwiązania prawnego. Przykładem jest tutaj zagadnienie kazirodztwa. W polskim prawie karnym mamy do czynienia $\mathrm{z}$ ustawową penalizacją kazirodztwa, która została ujęta w art. 201 ustawy z dnia 6 czerwca 1997 r. - Kodeks karny (Dz.U. z 1997 r. Nr 88, poz. 553 ze zm.; dalej: k.k.). Jego treść brzmi: „Kto dopuszcza się obcowania płciowego w stosunku do wstępnego, zstępnego, przysposobionego, przysposabiającego, brata lub siostry, podlega karze pozbawienia wolności od 3 miesięcy do lat 5".

Związana z poruszanym tematem pozostaje kwestia dobra prawnego, które przepis ten ma chronić i przyjmuje się w ostateczności, że jest nim obyczajność - moralność. Wydaje się to najbardziej przekonujące, biorąc pod uwagę obecną ustawę. Zasadnym nie jest tu argument eugeniczny, u którego podstaw tkwiło przekonanie, że u potomstwa, będącego owocem związku między krewnymi, istnieje większe prawdopodobieństwo wystąpienia wad genetycznych. Należy

*Uniwersytet Łódzki, Wydział Prawa i Administracji, jasiu.okonski@poczta.onet.pl. 
się jednak zastanowić, na ile tenże argument jest istotny z uwagi na samą treść art. 201 k.k. oraz brak innych przepisów o charakterze eugenicznym - np. przepisu w kodeksie karnym przewidującego karę za palenie papierosów w ciąży (Kozłowska-Kalisz 2016, 51).

Niemiej jednak powołanie się na eugeniczną podstawę penalizacji kazirodztwa obecne jest w orzecznictwie sądowym. Istotny przykład stanowi wyrok Sądu Apelacyjnego w Krakowie z dnia 4 kwietnia 1991 r., w którym zostało stwierdzone: „Przepis ten [dawny art. 175 k.k. z 1969 r.], chroni nie tylko względy eugeniczne ewentualnego potomstwa osób w nim oznaczonych, ale i stosunki rodzinne między tymi osobami, zwłaszcza obyczajność tych stosunków" (wyr. SA w Krakowie z dnia 4 kwietnia 1991 r., II AKz 28/91). Z treści wyroku wynika, że jednym $\mathrm{z}$ dóbr prawnie chronionych przez przepis według zaprezentowanego stanowiska, obok „względów eugenicznych ewentualnego potomstwa”, jest też obyczajność stosunków w rodzinie.

Ponadto, co pozostaje tutaj istotne, przywołany przepis tylko wycinkowo zdaje się mieć na celu ochronę prawidłowego funkcjonowania rodziny, albowiem penalizacji nie podlega zaspokajanie popędu seksualnego w jej ramach, jeżeli nie stanowi obcowania płciowego, może więc być także inną czynnością seksualną. Trudno zatem apodyktycznie stwierdzić, że przepis ten ma na celu zapewnienie prawidłowego funkcjonowania rodziny i ochronę prawidłowych relacji między rodzicami a dziećmi (Kozłowska-Kalisz 2016, 55).

Pojawia się tu jeszcze jedno pytanie: czy uzasadnieniem przepisu rzeczywiście może być ochrona wolności seksualnej? Można przyjąć, że penalizację kazirodztwa można uznać za stanowiącą w praktyce ingerencję ustawodawcy w sferę wolności seksualnej, skoro penalizacji podlegają też stosunki między spokrewnionymi, dorosłymi ludźmi, odbywające się w ramach konsensusu (tamże, 57). Sam art. 201 k.k. znajduje się w rozdziale XXV k.k., który jest poświęcony przestępstwom przeciwko wolności seksualnej i obyczajności, ale z poprzednich rozważań nasuwa się wniosek, co zostało zauważone we wstępie, że jedynym dobrem prawnym, które na pewno jest tu chronione, pozostaje obyczajność.

Podstawą pozytywizmu prawnego natomiast jest twierdzenie o braku związku pomiędzy moralnością a prawem, a samo dobro prawne chronione przez przepis art. 201 k.k. jest trudne do uchwycenia. Dobrem prawnym, które w ostateczności można przyjąć za chronione przez przepis, pozostaje obyczajność, jednak ratio legis ochrony tego dobra prawnego pozostaje trudne do określenia z uwagi na jego dość abstrakcyjny charakter. Ustawodawca nie przedstawia nam legalnej definicji obyczajności w omawianej ustawie. Odpowiedź na pytanie, czym w takim ujęciu może być „obyczajność”, pojawia się w treści uzasadnienia uchwały Sądu Najwyższego z dnia 13 kwietnia 1977 r., wedle którego są to: ,podstawowe moralne zasady współżycia społecznego w zakresie przeżyć, kontaktów i związków seksualnych" (uchw. SN z dnia 13 kwietnia 1977 r., VII KZP 30/76). We wskazanym uzasadnieniu uchwały Sąd Najwyższy, definiując „obyczajność”, odwołuje się 
zatem wprost do zasad moralnych „współżycia społecznego" również w zakresie „związków seksualnych”.

Mamy zatem do czynienia z relatywnie trudnym do uzasadnienia stanowiskiem o zasadności penalizacji kazirodztwa na gruncie obecnej regulacji prawnej (Warylewski 2008, 82). Możemy jednak dość stanowczo stwierdzić, że próba jego depenalizacji spotkałaby się z bardzo nieprzychylną reakcją ze strony polskiego społeczeństwa. Jako przykład może tu posłużyć znana sprawa wpisu, który prof. Jan Hartman zamieścił na swoim blogu internetowym, a który dotyczył propozycji Niemieckiej Rady Etyki, aby odstąpić od prawnokarnego zakazu kontaktów o charakterze seksualnym między dorosłym rodzeństwem. Wpis wywołał bardzo silne reakcje zarówno w środowisku akademickim, jak i wśród opinii publicznej. W konsekwencji tych zdarzeń wobec prof. Hartmana została wszczęta procedura dyscyplinarna, a on sam usunięty z partii politycznej, do której należał (Płatek 2016, 158).

Czy zatem można traktować obecny przepis jako wyraz pewnej reguły prawa naturalnego, która ma swoje podstawy w prawie moralnym i obyczajowości? Wyraz temu daje przytoczone wcześniej uzasadnienie uchwały Sądu Najwyższego. Możemy przyjąć, że prawo naturalne jest prawem powszechnym, niezmiennym i absolutnym (Woleński 2006, 32). Przy takim założeniu należy udzielić odpowiedzi przeczącej na to pytanie, albowiem znajoma nam penalizacja kazirodztwa nie jest zjawiskiem absolutnie uniwersalnym - badania ludów pierwotnych Afryki i Oceanii wskazują na różne spektrum negatywnego odbioru zjawiska wśród tych społeczności, choć oczywiście najczęściej mamy do czynienia z piętnowaniem relacji kazirodczych i traktowaniem kazirodztwa jako społecznego tabu (Kakareko 2016, 225). „Badania wielowiekowego dziedzictwa kulturowego społeczności Afryki, Ameryki i Azji pozwalają na postawienie tezy o braku uniwersalnego charakteru jednoznacznie negatywnej oceny zjawiska relacji kazirodczych" (tamże, 225). Dla przykładu - na półwyspie Gazelle na wyspie Nowa Brytania, należącej do Papui-Nowej Gwinei, młody mężczyzna powinien wyprowadzić się z domu matki i ma zakaz wchodzenia do niego, jeżeli znajdują się w nim jego siostry. Z drugiej strony w jednym z plemion w Północnej Kolumbii karą za czyn kazirodczy było ponowne popełnienie tego czynu, ponieważ wedle wierzeń plemienia Kagaba tylko jego powtórzenie mogło ustrzec grzesznika przed gniewem ducha seksualności Kheisei (tamże, 227). W Europie natomiast jeszcze w wieku XIX występował na rosyjskiej wsi zwyczaj snochactwa, czyli utrzymywania przez ojca stosunków seksualnych z żoną syna, choć czyn ten zagrożony był karą pozbawienia wolności.

Kazirodztwo było zjawiskiem szczególnie znamiennym dla wyższych warstw społeczeństwa, na przykład w czasach rządów Ptolemeuszy w Egipcie, gdzie było traktowane jako zjawisko akceptowalne, jak również w Europie wśród członków dynastii Habsburgów (Kociuba 2016, 310). Warto nadmienić, że obecnie także istnieją państwa, takie jak Hiszpania, Portugalia, Belgia, 
Holandia i Francja, w których zrezygnowano z penalizacji stosunków kazirodczych dorosłych, odbywających się w ramach konsensusu stron, właśnie $\mathrm{z}$ racji istnienia owej zgody. We Francji prawnokarny zakaz kazirodztwa został zniesiony ponad 200 lat temu, za sprawą kodeksu karnego Napoleona z 1810 r. Stanowi to kolejny argument przeciwko twierdzeniu o uniwersalnym charakterze tego prawnokarnego zakazu (tamże, 309-310). Nie sposób nie zauważyć, że wielka zmiana $\mathrm{w}$ kwestii podejścia do kazirodztwa nastąpiła na przełomie wieku XVIII i XIX. Stało się tak za sprawą myśli epoki oświecenia i racjonalistycznego podejścia do kwestii tych przestępstw, które naruszać miały obyczajność lub moralność przyjętą w społeczeństwie. W konsekwencji przestano powszechnie postrzegać kazirodztwo jako obrazę ,praw boskich”, a zwrócono na nie uwagę z perspektywy szkody wyrządzanej człowiekowi. Zwrot ten spowodował również zmianę w zakresie prawnokarnej klasyfikacji kazirodztwa, które zamiast zbrodni zaczęło być traktowane łagodniej, jako występek lub wykroczenie. Dla przykładu - w ten sposób uregulowano kazirodztwo w Landrechcie pruskim z 1794 r., w którym rozumiane było jako stosunek płciowy między osobami połączonymi więzami pokrewieństwa, a zostało zakwalifikowane jako występek cielesny, przy czym przewidywany wymiar kary zależny był według przepisów Landrechtu od tego, pomiędzy kim dochodzi do kazirodztwa (Smyk 2016, 34-35).

Z powyższych obserwacji wynika, że obyczajowość społeczeństw zachodnich wpływa na konstruowanie przez nich norm iuris positivi, dotyczących zjawiska kazirodztwa w innym kształcie niż ten nam znany.

Jak widać, pierwsze stanowisko, które określa się jako maksymalizm prawnonaturalny, przyjmuje szczególne silne podstawy reguł prawa naturalnego, takie jak absolutność, nieodwołalność, niezmienność (Woleński 2006, 31). W odniesieniu do zjawiska kazirodztwa sugerowanie, że mamy w jego wypadku do czynienia $\mathrm{z}$ pewną uniwersalną regułą prawnonaturalną, jest trudne do utrzymania.

Istnieje również koncepcja minimum prawa natury albo minimum treści prawa naturalnego autorstwa Herberta L.A. Harta (Hart 1998). Uznał on, że istnieją określone fakty, które wywierają wpływ na treść prawa, na przykład: egzystencja człowieka w społeczeństwie i związane z nią fizyczne ograniczenia jednostki, jej nie zawsze równa pozycja w stosunku do innych członków społeczeństwa, ograniczony altruizm, a także ograniczona liczba możliwych do wykorzystania zasobów (tamże, 261-265). Przytoczone fakty, tworzące podstawowe zręby prawa naturalnego, zdają się być tak oczywiste, że określane są przez Harta mianem truizmów (tamże, 261). W konsekwencji te trywialne okoliczności powodują istnienie w prawie określonych reguł (Woleński 2006, 37). Koncepcja Harta stoi w opozycji do twierdzenia twardego pozytywizmu, wedle którego „,prawo może mieć jakąkolwiek treść", wyklucza tym samym jakiekolwiek związki prawa z moralnością, przez co pozbawioną znaczenia staje się kwestia moralności norm prawa pozytywnego. 
Biorąc pod uwagę taką perspektywę, penalizacja kazirodztwa odgrywa swoją rolę jako rodzaj pewnej wartości, która choć nie jest uniwersalna, to będzie akceptowalna w wielu kulturach - jako mająca na celu ochronę obyczajności. $\mathrm{Na}$ dalszy plan schodzi kwestia źródła tej reguły - tego, czy ma ona charakter tylko obyczajowy, czy może i religijny. U Harta takimi źródłami są trwałe cechy ludzi oraz świata, w którym żyją (Hart 1998, 269).

Oczywiście, co warto nadmienić, przyjmuje się, że kazirodztwo jest czymś negatywnym i niepożądanym. Nie można tego, ponad wszelką wątpliwość, wywnioskować $\mathrm{z}$ istoty samego zjawiska kazirodztwa, ponieważ mamy tutaj do czynienia z logiczną niemożliwością wywodzenia zdania normatywnego (powinnościowego) ze zdania nienormatywnego (Woleński 2006, 33). Jest to zagadnienie tzw. gilotyny Hume'a. Biorąc jednak pod uwagę koncepcję Harta, wydaje się, że trudno jednoznacznie stwierdzić, jakie okoliczności związane z egzystencją człowieka w świecie mogłyby powodować bardzo negatywny stosunek ludzi, wyrażany w ludzkiej obyczajowości, do zjawiska konsensualnego kazirodztwa dorosłych, jeżeli nie byłyby nimi względy eugeniczne. Według Harta istnienie minimalnej treści prawa naturalnego w prawie, która to treść jest związana z jej źródłami wcześniej wymienionymi, ma służyć minimalnemu celowi - zapewnieniu człowiekowi i społeczeństwu przetrwania (Hart 1998, 199 i 261).

Każda koncepcja prawa naturalnego ma charakter normatywny, w tym sensie, że wskazuje, jak powinny wyglądać normy prawa pozytywnego. Jak w Historii seksualności zauważa Foucault: „Skoro przyjmiemy, że u progu każdej kultury stoi zakaz kazirodztwa, wówczas seksualność okaże się od początku czasów umiejscowiona pod znakiem prawa i prawodawstwa" (Foucault 2000, 98).

Obecna ustawa respektuje wskazane minimum prawa naturalnego, które akceptowane jest przez naszą kulturę, negatywny stosunek do kazirodztwa ma swoje źródło w podłożu religijnym i kulturowym. Duży wpływ na kształtowanie się tego przekonania miało nauczanie Kościoła Rzymskokatolickiego. Kazirodztwo piętnowane jest zarówno w księgach Starego Testamentu, w szczególności w Księdze Kapłańskiej, jak i Nowego Testamentu (Warylewski 2008, 80). W Liście do Koryntian święty Paweł potępia zachowanie tych wiernych, którzy współżyją z żoną swego ojca, nazywając takie zjawisko mianem rozpusty (1 Kor 5, 1). Jednak odwołując się do Biblii, możemy wskazać także, że Sara, żona Abrahama - pierwszego patriarchy narodu wybranego, była jego przyrodnią siostrą.

W encyklice Evangelium Vitae z 1995 r. papież Jan Paweł II stwierdza, że stosunki seksualne osób, które widzą w prokreacji przeszkodę, stanowią wypaczenie i są sprzeczne z istotą małżeństwa oraz z osobowością człowieka, która prawdziwy sens może uzyskać w ramach cywilizacji życia (Jan Paweł II, 11). Sam Katechizm Kościoła Katolickiego określa kazirodztwo jako wykroczenie przeciw godności małżeństwa i jako szczególnie ciężki grzech (KKK 2002, 2388). Wielosetletnia aktywność chrześcijańskiego duszpasterstwa krzepiła naukę Kościoła na ziemiach polskich i europejskich, przyczyniając się do przyjmowania przez 
ludność zasad o charakterze moralnym, w znaczny sposób dotyczących nie tylko kazirodztwa, ale i seksualności w ogóle. Uniwersalizacja tych przekonań szła w parze ze wzrostem znaczenia modelu seksualności, w którym głębsze znaczenie uzyskała silna wstrzemięźliwość, nieuleganie bodźcom o naturze seksualnej, co na przykład objawia się w ascetycznym życiu chrześcijańskiego eremity albo w regule zakonnej, budowanej wokół idei monastycyzmu. Widoczne jest to także w ramach postulowanej moralności, jaka ma istnieć w chrześcijaństwie pomiędzy kobietą a mężczyzną w małżeństwie (Foucault 2000, 160). Z drugiej strony innym elementem tego modelu jest problematyka związana $\mathrm{z}$ umiejscowieniem przyjemności seksualnej w jego ramach, którą Foucault określił jako ekstremalną (tamże, 180).

Istotna pozostaje również kolejna kwestia - art. 201 k.k. jest wyrazem pewnej reguły prawa naturalnego, przyjmującej za niedopuszczalne kontakty seksualne między osobami spokrewnionymi. Biorąc pod uwagę konstrukcję przepisu, rozumianego w tym kontekście też jako wyraz moralno-obyczajnego piętnowania kazirodztwa, mogą się pojawić pewne trudności po jego analizie z punktu widzenia regulacji międzynarodowych. Otóż art. 201 k.k. przewiduje normę sankcjonującą również w przypadku stosunków nawet między niespokrewnionymi biologicznie, dorosłymi ludźmi, na przykład między przysposobionym a przysposabiającym, które odbywają się za ich wspólną zgodą. Bez wątpienia możemy to potraktować jako naruszenie wolności seksualnej człowieka, zagwarantowanej między innymi w Powszechnej Deklaracji Praw Seksualnych Światowej Organizacji Zdrowia z 2002 r., w której jest rozumiana jako indywidualna możliwość jednostki do wyrażania pełni potencjału seksualnego, wykluczającego jednak wszelkie formy seksualnego przymusu, wykorzystywania i nadużyć w jakimkolwiek czasie i sytuacji życiowej.

Warto przypomnieć, że takiego rodzaju zjawiska kazirodcze - obcowanie płciowe dorosłych krewnych - zostały zdepenalizowane w kilku państwach europejskich. Jak zostało wcześniej stwierdzone, w 2014 r. Niemiecka Rada Etyki zarekomendowała, aby odstąpić od karania dobrowolnych stosunków seksualnych między dorosłym rodzeństwem (Kociuba 2006, 309). Rozwiązania prawne tych państw nadal spełniają jednak pewne minimum prawa natury w odniesieniu do wybranych reguł moralnych, jakich ich społeczeństwa wymagają od penalizacji kazirodztwa. Dla przykładu - nadal mamy do czynienia z penalizacją obcowania płciowego osoby nieletniej z jej spokrewnionym krewnym, również wtedy, kiedy odbyło się to za jej zgodą. Reguły te wciąż stanowią ochronę przed seksualnym wykorzystywaniem członków rodzinny, co ma również miejsce na gruncie polskiego rozwiązania prawnego z art. 201 k.k.

Można natomiast przyjąć, biorąc pod uwagę rozwój rozwiązań prawnych w państwach europejskich oraz spór prawa pozytywnego z prawem naturalnym, że istnieje tendencja do depenalizacji konsensualnego obcowania płciowego dorosłych osób spokrewnionych. W wielu państwach ma zatem miejsce 
przełamywanie tabu kulturowego - jednego z najsilniejszych, jakie istnieją w naszej kulturze. Pomimo atomizacji społeczeństwa i deprecjacji znaczenia rodziny jako najważniejszej komórki społecznej, a także niebagatelnego wzrostu indywidualizmu w ciągu ostatnich 100 lat, obyczajowo-moralne tabu kazirodztwa nadal budzi żywe emocje. Podobne siły, które doprowadziły do zmian kulturowych, a które zaowocowały na przykład depenalizacją stosunków homoseksualnych, nie zdołały zmienić społecznego nastawienia wobec zjawiska kazirodztwa choćby w podobnym stopniu. Tabu kazirodztwa jest na tyle głęboko zakorzenione w naszym społeczeństwie, że mało prawdopodobna wydaje się zmiana regulacji prawnej w tym zakresie, nawet jeśli mogłaby ona polegać na doprecyzowaniu i wyklarowaniu przepisu art. 201 k.k. w celu usunięcia problemów z nim związanych, wokół których ogniskuje się obecnie krytyka ze strony doktryny.

Reasumując, możemy stwierdzić, że dobrem chronionym przez art. 201 k.k. jest obyczajność, a minimum prawa naturalnego wyrażone jest w tym wypadku w penalizacji kazirodztwa, które znajduje swe źródło w obyczajowości i jest obecne w prawie stanowionym pod postacią art. $201 \mathrm{k} . \mathrm{k}$.

\section{BIBLIOGRAFIA}

Foucault, Michel. 2000. Historia seksualności. Tł. Bogdan Banasik, Tadeusz Komendant, Krzysztof Matuszewski. Warszawa: Czytelnik.

Hart, Herbert Lionel Adolphus. 1998. Pojęcie prawa. Tł. Jan Woleński. Warszawa: Wydawnictwo Naukowe PWN.

Kakareko, Ksenia. 2016. „Kazirodztwo a zmiany społeczno kulturowe rodziny”. W Kazirodztwo. Red. Marek Mozgawa. 223-239. Warszawa: Wolters Kluwer.

Kociuba, Jolanta. 2016. „Psychospołeczne i kulturowe uwarunkowania kazirodztwa”. W Kazirodztwo. Red. Marek Mozgawa. 308-328. Warszawa: Wolters Kluwer.

Kozłowska-Kalisz, Patrycja. 2016. „Racjonalizacja penalizacji kazirodztwa”. W Kazirodztwo. Red. Marek Mozgawa. 47-61. Warszawa: Wolters Kluwer.

Płatek, Monika. 2016. „Kodeksowe ujęcie kazirodztwa - pozorny zakaz i pozorna ochrona”. W Kazirodztwo. Red. Marek Mozgawa. 124-163. Warszawa: Wolters Kluwer.

Smyk, Grzegorz. 2016. „Kazirodztwo jako przedmiot regulacji nowożytnych kodyfikacji prawa karnego". W Kazirodztwo. 32-46. Red. Marek Mozgawa. Warszawa: Wolters Kluwer.

Warylewski, Jarosław. 2008. „Przywilej bogów”. W Fascynujące ścieżki filozofii prawa. Red. Jerzy Zajadło. 79-90. Warszawa: LexisNexis.

Woleński, Jan. 2006. „Czy prawo naturalne daje się uzasadnić”. W Prawo, władza. społeczeństwo, polityka. Księga Jubileuszowa Profesora Krzysztofa Pałeckiego. Red. Maria Borucka-Arctowa i in. 31-37. Toruń: Wydawnictwo Adam Marszałek.

Zirk-Sadowski, Marek. 2000. Wprowadzenie do filozofii prawa. Kraków: Kantor Wydawniczy Zakamycze.

\section{Źródla}

Jan Paweł II. 1995. Evangelium Vitae. https://w2.vatican.va/content/john-paul-ii/pl/encyclicals/documents/hf_jp-ii_enc_25031995_evangelium-vitae.pdf [dostęp 30.03.2018].

Katechizm Kościoła Katolickiego (KKK). 2002. Poznań: Pallottinum. 
Pismo Święte Starego i Nowego Testamentu w przekładzie z języków oryginalnych. 2000. Wyd. 5. Oprac. Zespół Biblistów Polskich z inicjatywy Benedyktynów Tynieckich, Poznań: Pallottinum.

Powszechna Deklaracja Praw Seksualnych Światowej Organizacji Zdrowia. [Ostatnia modyfikacja 2013]. http://www.worldsexology.org/wp-content/uploads/2013/08/DSR Polish.pdf [dostęp 4.02.2018].

\title{
Orzecznictwo
}

Wyrok SA w Krakowie z dnia 4 kwietnia 1991 r., II AKz 28/91. http://lex.uni.lodz.pl [dostęp 30.03.2018].

Uchwała SN z dnia 13 kwietnia 1977 r., VII KZP 30/76. http://lex.uni.lodz.pl [dostęp 30.03.2018].

\section{Akt prawny}

Ustawa z dnia 6 czerwca 1997 r. - Kodeks karny (tekst jedn. Dz.U. z 1997 r. Nr 88, poz. 553 ze zm.).

\author{
Jan Okoński
}

\section{INCEST AS AN EXAMPLE OF A CONFLICT BETWEEN NATURAL LAW AND POSITIVE LAW}

\begin{abstract}
This paper discussed incest as an example of a dispute between natural and positive law. An analysis of Art. 201 of the Polish Penal Code was conducted through the prism of legal goods, which, according to the doctrine, Art. 201 is supposed to protect. The article assessed the prohibition of incest as a kind of legal and natural norm, both from the point of view of the classic, maximalist concept of natural law and H.L.A. Hart's minimum content of natural law. The article then refers to a significant lack of universality of penalization of this phenomenon across legislations of other European states. The author assumed that the Polish statutory penalization of incest met the conditions of the concept of the minimum content of natural law. Therefore, it may be treated as an expression of the legislator's acceptance of the protection of moral principles, which are present in Polish culture.
\end{abstract}

Keywords: incest, natural law, positive law, criminal law, Hart. 